\title{
Modeling of Conservation Priority Zone for the Helmeted Hornbill (Rhinoplax Vigil) In Silokek Geopark Area, West Sumatra
}

\author{
Rizki Atthoriq Hidayat*, Natasyah Febriani, Muhammad Hanif, Henzulkifli Rahman \\ Geography Science, State University of Padang, Padang 25132, Indonesia \\ *Correspondence: email. Rizkiatthoriq99@gmail.com
}

\begin{abstract}
Helmeted hornbill (Rhinoplax vigil) is a protected wildlife in Indonesia according to enactment no. 5, 1999 about Conservation of Natural Resources and its Ecosystems and Government Regulation no. 9, 1999 about plant and wildlife preservation. Helmeted Hornbill habitats spread in five country regions: Myanmar, Thailand, Malaysia (Malayan Peninsula and Serawak), Brunei, and Indonesia (Sumatra and Borneo). Silokek Geopark which located in Sijunjung Regency, West Sumatra Province, Indonesia is an identified location of Helmeted Hornbill habitat existence. Beside its uniqueness in physics, this bird also have an ecological function as seed dispersal in nature. The utilization of Remote Sensing (RS) technology and and Geographic Information System (GIS) is highly useful in identification the Helmeted Hornbill habitat distribution in this research. Geographic dateset used in this research are Landsat OLI 8 imagery, Shuttle Radar Topographic Model (SRTM), Coordinate points of Helmeted Hornbill existence and location assesment, and other dataset related to administration boundary in Silokek Geopark. This research aims to find conservation priority zone of Helmeted Hornbill in Silokek Geopark. By utilizing Maximun Entropy (MaxEnt) algorithm with finding points and location assessment, we can determine the distribution of Helmeted Hornbill habitat in Silokek Geopark based on habitat likeness. This research produces the model of conservation priority zones in geopark silokek which are distributed in hilly protected forest area and the distributions are concentrated in the center and noth east part of our researc area. This model is highly influenced by forest texture $(25.7 \%)$, distance of patches $(24.3 \%)$, and distance of settlement.
\end{abstract}

Keywords: habitat modeling; helmeted hornbill; conservation

\section{Introduction}

Hornbill is a very unique and exotic bird species. This species is protected in Indonesia according to enactment no. 5, 1999 about Law Conservation of Natural Resources and its Ecosystems and Government Regulation no. 9, 1999 about plant and wildlife preservation. Assessment from IUCN Helmeted Hornbill in Red List Category and Critically Endangered (CR) species and listed in Appendix 1 by CITES.

Helmeted hornbills Rhinoplax vigil are unique among the Bucerotiformes in having solid 'ivory' casques that are used sometimes in aerial displays where individuals collide casque-to-case que in mid-air (Kemp 1995). The morphology of helmeted hornbill is easily recognized, because the large size with a longer middle tail. The sizes of the ivory hornbills are as follows: more less $140 \mathrm{~cm}$ total length; wing length between $42-48 \mathrm{~cm}$ with wing length females tend to be shorter; the length of the middle tail feathers ranges from $60-77 \mathrm{~cm}$ and the side tail lengths of about $30-38 \mathrm{~cm}$; The length of the beak ranges from 16.2 to $20.4 \mathrm{~cm}$, while the length of the ivory ranges from $7.3-9.4 \mathrm{~cm}$. The hair of the ivory hornbill is dominated by black, brown and white. The wings are black with white tips, with brownish wing feathers. The chest hair is black, while from the upper abdomen to the lower tail cover it is white. The side tail is white with a black band before the tip. The beak and ivory are red, except for the ivory in the front and about half the beak to the tip which is ivory (KLHK. 2018).

Helmeted Hornbill distributed in Sumatra and Borneo, six locations are recently identified as Helmeted Hornbill existence are three in Borneo and thee in Sumatra regions comprising Kutai National Park, Barito Ulu, international corporation of Indonesia in east Borneo, Hutan Harapan - Jambi, Bukit Barisan Selatan National Park, and entire part of Lampung Province. Helmeted Hornbill generally tend within the forest which far from human activity. Nur (2013) has found 16 individual helmeted hornbills in Solok Selatan West Sumatra. Nevertheless, in Goepark Sikokek West Sumatra there has many biodiversity including helmeted live in the natural land scape (Kusuma. 2019). From the land cover map of 2014 it has revealed about 27,4 million hectares of primary dry forest cover had potential for Helmeted Hornbill habitat in Sumatra (Kumara. 2006; KLHK, 2018). The condition highly support for the sustainability of this species. Largely, It occupies lowland forest habitats (Jain et. al, 2018). it appears to prefer hilly terrain away from the coast $(300-1,100 \mathrm{~m}$, occasionally to $1,500 \mathrm{~m}$ ) but there are significant 
strongholds in some lowland forest areas. This locations where the Helmeted Hornbill distribution it have annual rainfall $>3000 \mathrm{~mm}$ (Kinniard and O'Brien, 2007). In prime habitat, recorded average density in Sumatra varies is from 0.19 to $2.6 \mathrm{birds} / \mathrm{km} 2$ depending on habitat quality and latitude (Jain et. al, 2018). Helmeted Hornbill also found in logged secondary forest in Jambi which still holds large trees which height attain $30 \mathrm{~m}$ or more, and $30 \mathrm{~m}$ of free branches height (Azizah, 2010). Helmeted Hornbill home range size has not been estimated, and so far no radio or satellite tagging has been attempted (Jain et. al, 2018).

Selective living requirements of Helmeted Hornbills makes them occur in only particular locations depending on food supply, secutiry, and comfortability which support the habitat suitability. Disconsertingly, little is known about the basic biology and ecology of the species (Kaur et. al., 2019). It extends into adjacent mature secondary forest, but avoids open areas, disturbed forest and peat swamps (Kinnaird \& O'Brien, 2007; Lum \& Poonswad, 2005; Poonswad et al., 2013)As the availability of suitable nest sites plays a major role in population recruitment of cavity-nesters (Cody 1985). The Helmeted Hornbill has the most specialised diet of any hornbill, largely consisting of fruits(Jain et. al, 2018). Up to $60 \%$ of its diet may consist of six or seven fig species (Poonswad et al., 2013; Kitamura et al., 2011). In Sumatra, about $98 \%$ of its foods are ficus (Hadiprakarsa \& Kinnaird, 2004). Hornbills play an important role as seed dispersal agents for tropical forest regeneration (Kinnaird \& O'Brien 2007; Walker 2007; Kitamura 2011; Naniwadekar et al. 2015; Corlett 2017), Sometimes when male feeding the female and cheeper to the nest, it falls the fruits to the ground. It could disperse various fruits and seeds far away from the origin because of it wide cruising range (KLHK,2018).

Beside habitat loss due to deforestation and land use transformation, helmeted hornbill population also significantly declined by poaching activity. The population is currently believed to be undergoing rapid decline as a consequence of extensive poaching in Indonesia (Sumatra) (BirdLife International, 2017; Krishnasamy et al., 2016). Helmeted Hornbills are hunted to supply strong demand for their solid casques (Jain et. al, 2018). This condition pushed the number of Helmeted Hornbill population. Just two seizures were reported from Sumatra, the first (involving 48 heads) in Padang, capital of West Sumatra province, in April 2013, the second (involving seven beaks) in Jambi province in May 2014 (C. Bastall et. al, 2016). Environmental management and conservation agendas commonly include requirements for mapping and monitoring wildlife habitat for the purpose of estimating population sizes, identifying critical habitat, and predicting the impacts of environmental change (McDermid et. al., 2005). Sustainable conservation action is needed to deploy toward Helmeted Hornbill habitat because their habitat occupancy already decline followed by hunting and trading this wildlife. During the last decades, progress in remote sensing technology is increasingly contributing to the identification and quantification of species, structures and objects relevant for habitat quality monitoring (Lengyel et. al., 2008).

The area of National Geopark Silokek is located in administration of District Muaro Silokek and Durian Gadang, by the larges area is more less $300 \mathrm{~km}$ (Muharram et al. 2020). Geopark Silokek is also as home to protected flora and fauna. Some protected wildlife in this area are Sumatran Tiger (Panthera tigris sumatrae), Tapir (Tapirus indicus), Anteater (Manis javanica), and Helmeted Hornbill (Buceros vigil) (Kusuma. 2019). The biodiversity is richness of this geopark it has support by ecosystem tropical rain forest, big river (Indragiri River), and wildlife within. In this research, we bordered the location as a region of interest in area of 65540.66 hectares $\left(655.41 \mathrm{~km}^{2}\right)$. There are 7 sub-districts and 18 villages in our research location. This location is dominated by forests on hilly landscape, and particularly in southwestern part is dominated by plantations and rice fields. In Geopark Silokek the one of many endemic species in this area is helmeted hornbill. Purpose of this research is to This study aims to modeling the suitability habitat as the conservation priority, measuring priority conservation area, and determining the highest variable contribution in modeling the conservation priority zone.

\section{Methodology 2.1 Image Analysis}

In this research there has utilized a digital image of Landsat OLI 8 and SRTM (Shuttle Radar Topographic Mission) this data free access from website USGS (United States Geological Surveys) which the cell resolution is $30 \times 30$ meters. These images has processed using is Maximum Likelihood as the supervised classification for extraction imagery to land cover map on Geopark Silokek. This method is a pixel based classification. Supervised classification techniques in contrast, use intensive hands-on training in an attempt to extract predefined information classes from the explanatory, and, as such, require specific a priori knowledge (McDermid et. al., 2005). The maximum likelihood classification is the most effective classification method if equipped by accurate training data and one of the most used algorithm (Perumal and Bhaskaran, 2010). This image classification works by accumulating the pixel values from marked polygon samples of a land use class, then other an unmarked location which has the same pixel value with marked 
location will be in one class with marked polygon samples. These land use Geopark Silokek then processed for environmental variables as our consideration to determine the conservation priority zone for the helmeted hornbill. There is also apply NDVI (Normalized Difference Vegetation Index) algorithm to obtain the forest texture by quantifying NDVI. Nevertheless there used SRTM imagery to extraction elevation (automatically exist, because this data contains point $\mathrm{z}$ information) and slope. All of data as our environment variables then would be statistically quantified in MaxEnt software to gain the main result of this research.

\subsection{Transformation to Logarithm Natural (ln)}

This process value transformation is intended to distance variables (river, settlement, agriculture, and patch). Firstly, the raw datasets of these variables were calculated with euclidean distance algorithm. The distance is calculated from the center of a feature into other feature center, which the highest value is in the middle cell of both distance and the lowest value is in the source cell. The reason why we modify the raster value of these variables with logarithm natural is to give the natural effect and enhance the result especially the model look sharper. Each distance variable values is estimated in the calculation of distance $e$ 'di transformation. The distance by euclidean distance is massively represented. We consider that the natural effect to other environment is not as that massive. So, we need to convert the value of the euclidean distance to get natural effect by using logarithm natural $(\ln )$. The transformation is stated with this equation (Hanif, et al. 2020):

$$
\begin{aligned}
& e^{\prime} d=\ln (1+e d) \\
& e^{\prime} d i=\left(\operatorname{Max} e^{\prime} d+1\right)-e^{\prime} d
\end{aligned}
$$

Where:

ed : input parameter (euclidean distance)

ln : logarithmic natural

e'd : output from logarithmic natural of ed

Max e'd : maximum raster of $e$ 'd

$e^{\prime} d i \quad:$ transformation of euclidean distance for input parameter.

$e^{\prime} d i$ value is the inverse of $e^{\prime} d$ value. The inversion of $e^{\prime} d$ value is because this value is no longer as the distance value but as the standardized value. Which means if the occur point is closer to the source feature, the raster value is higher.

\subsection{Species Present Data}

The present samples of helmeted hornbills were obtained in field observation. To get the data of this species, we did observation and searching them used binoculars, when we found the position this species on the tree, then plotting of coordinate points of the presence of this species was deployed by using Global Positioning System (GPS) cartometric approach. The records are also based spatial approach as the logic of this species to strengthen the final result the model. The recorded coordinate points then converted and processed to be readable in MaxEnt software.

\subsection{Environmental Variables}

Environmental variables are used for variable in MaxEnt to result the model paraller with species present data. These variables refer to the characteristics of species habitat. The suitability habitat shown by how the present species data interact with these variables, where the points condense will determine the result of this model. These environmental variables are slope, distance from river, forest texture, distance from settlement, elevation, distance from agriculture, and distance of patches. These variables will be analyzed more in the result and discussion part. These variables are chose to considering the topographic condition, food supply, inter-patches access, and the threat potential to habitat.

Distance of settlements and agriculture reveal the risk of threat because these are the distance of to reach the places where human activities. It extends into adjacent mature secondary forest, but avoids open areas, disturbed forest and peat swamps (Kinnaird \& O'Brien, 2007; Lum \& Poonswad, 2005; Poonswad et al., 2013) If the distance of this species is closer to these both variables, the accessibility of hunting will be easier. Despite of that forest texture gained from the image processing using NDVI algorithm. This variable is essential because it considers the nesting and food supply for this species. Helmeted Hornbill to known living in primary evergreen forest (KLHK, 2018). Plants in lowland tropical rain forest poses is various pattern conception like semi-annual, annual, and supra-annual, so that some trees could change simultaneously and others seasonally (KLHK, 2018). 


\begin{tabular}{cccc}
\hline No. & Variables & Source & Data type \\
\hline 1 & Forest Texture & NDVI equation & Categorical \\
2 & Elevation & SRTM imagery calculation & Continuous \\
3 & Slope & SRTM imagery calculation & Continuous \\
4 & Distance From River & $e^{\prime} d i$ calculation & Continuous \\
5 & Distance of Agriculture & $e^{\prime} d i$ calculation & Continuous \\
6 & Distance of Patches & $e^{\prime} d i$ calculation & Continuous \\
7 & Distance of Settlement & $e^{\prime} d i$ calculation & Continuous \\
\hline
\end{tabular}

\subsection{Maximum Entropy Modeling}

There are some methods used for Species Distribution Modeling (SDM). One of those is MaxEnt (Maximum Entropy). Maxent is recently introduced modeling technique, achieving high predictive accuracy and enjoying several additional attractive properties (Philips and Dudı'k, 2008). Maxent model is a machine learning/data mining program that evaluates the distribution probability of a species in relation to environmental factors (Yang, 2013; Philips, 2006; Philips, 2004). The maximum entropy algorithm is deterministic and will converge to the maximum entropy probability distribution (Philips et al., 2006). The basic principle of the statistical approach implemented in Maxent is the estimation of the probability of a distribution with maximum entropy (that is, the most spread out or the most uniform distribution) given a set of conditions (the environmental characteristics of the site where the species is detected) that shows our incomplete information regarding the distribution of the species (Phillips et. al., 2006). Runs were conducted with the default variable responses settings, and a logistic output format which results in a map of habitat suitability of the species ranging from 0 to 1 per grid cell,

Where in the average observation should be so close to 0.5 (Elith et. al., 2011). While the best result of this model should be close to 1 and closer to 0 the value will get worse. The one of the important information of MaxENt is AUC with showed model performance as < 0.7 (poor model performance), 0.7-0.9 (moderately/useful), and $>0.9$ (excellent) (Gunawan and Prasetyo.. 2013; Baldwin, 2009). Although methods employing presence/absence data are often prioritized, present only modeling approaches should be used when the objective is to identify suitable habitat of a given species, particularly when the current distribution of the species is unknown or has been dramatically altered (e.g., historical anthropogenic disturbances) (Brotons et al. 2004).

Maxent provides output data in raw, cumulative, and logistic formats (Philips and Dudı'k, 2008). Raw is a main format of Maxent Processing and the basis of the next processing with GIS tools as the for the analysis. The cumulative format is scale independent with scores for locations equal to the probability of finding the species of interest at that site plus all others with equal or lower probabilities (Baldwin, 2009). The logistic format is currently recommended given that it provides estimates of the probability of occurrence as predicted by included environmental variables (Philips and Dudı'k, 2008).

\section{Result}

\subsection{Environmental Variables}

Result of image analysis is land cover map, there has found land uses classification. Several information of this data has elected as environment variables. These variables determine this modeling. These variables were choosing based on the field condition geographically and the tendency this species occurs. The difference in the number of variables will also cause the difference in the result of species distribution modeling. So, in choosing the environmental variable, it is supposed to be selective and suitable with the essential spatial requirement of helmeted hornbill habitat. These variables are suspected have influence toward the helmeted hornbill habitat.

These environmental variables are slope, distance from river, forest texture, distance from settlement, elevation, distance from agriculture, and distance of patches. The Maxent algorithm will process these variables by considering the present data. For more detail how distribution the environmental variable on this research area, it present on the figure bellow. 


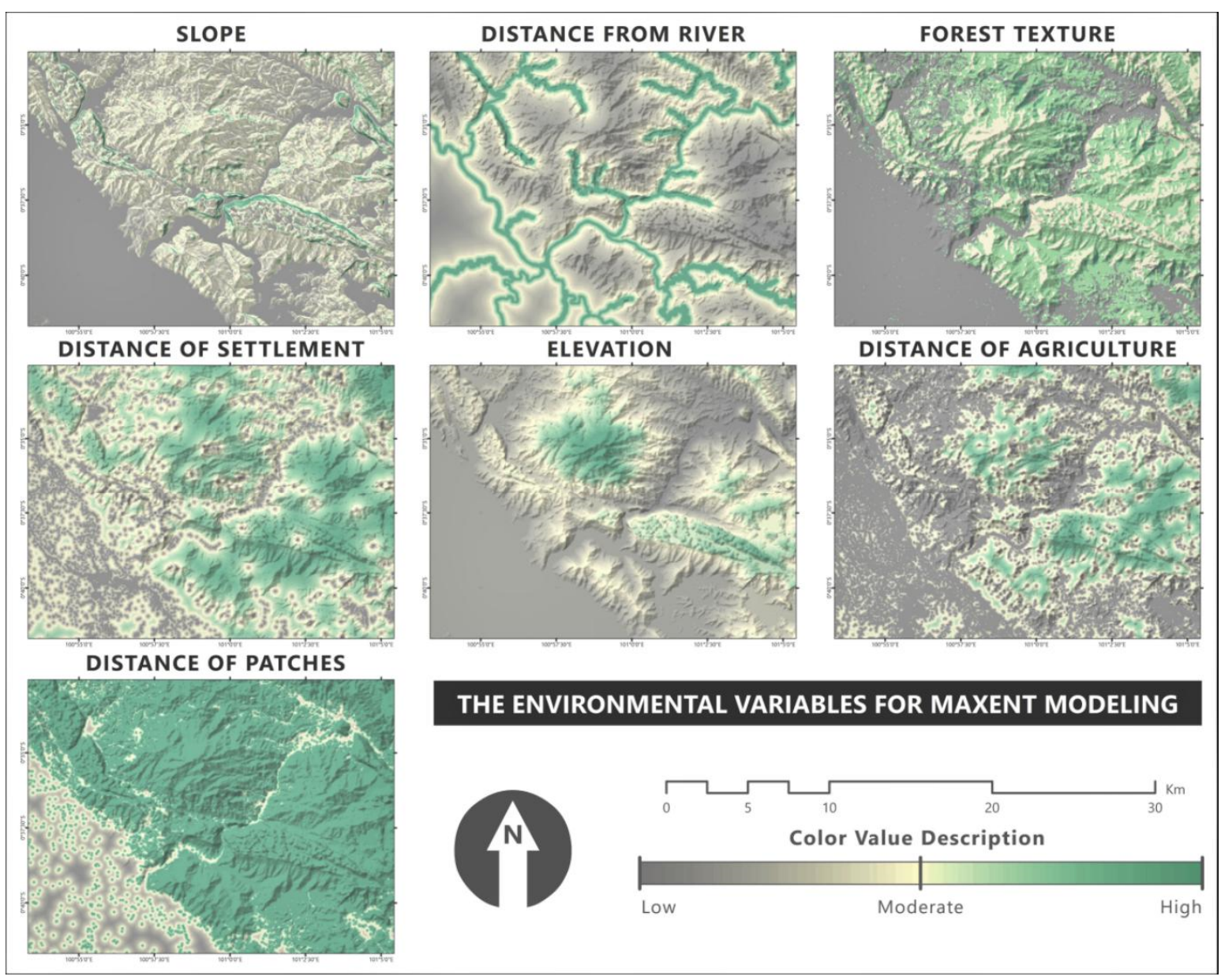

Figure 3. The environmental variable used in MaxEnt Modeling.

Land use type was extracted from process image classification. It is consist of forest, shrub, rice field, settlement, water body, and plantation. Where this land use, will be basic data to identify the Helmeted Hornbill habitat characteristic, but not all land use classes are used in this modeling as the environmental variables. The land cover class did select for Maxent Processing such as forest, settlement, rice field, and plantation.

Distance parameters including distance from river, settlement, agriculture, and distance of patch habitat. The energy from patch habitat will represent the level of connectivity of habitat centralization or even threats. Then distance from rivers and the distance of patches it has reveal the centralization potential habitat of Helmeted Hornbill, because the closer to both parameters the easier this species in inhabiting and gaining food to survive. Rivers provide the need of primary need of living (water) for all organisms and as the energy flow. Distance of patches is indicates how interaction among habitat to transfer the species can reach other habitat patches as the destination of migration or the area of exploration, if the distance of inter patch is close to other patch, it will ease the route of this species. Distance from settlement and agricultural area will affect how comfortable hornbills are in their habitat. When hornbills to often meet humans around their nests. He will feel insecure because this condition will disturb this bird. The human activity around the settlement it also will influence the landscape around this place, for example human will converting or cutting down trees for them necessary this activity will be pressure for them.

\subsection{Modeling of Conservation Priority Zone}

The relation between average sensitivity and fractional predicted area shown by picture below. Gained from repicated maxent model, this crve is the reveiver operating characteristic (ROC). The average training AUC score reached 0.923 with the standard deviation is 0.017. This result reveals high accuracy because the AUC value is nearly 1 . 


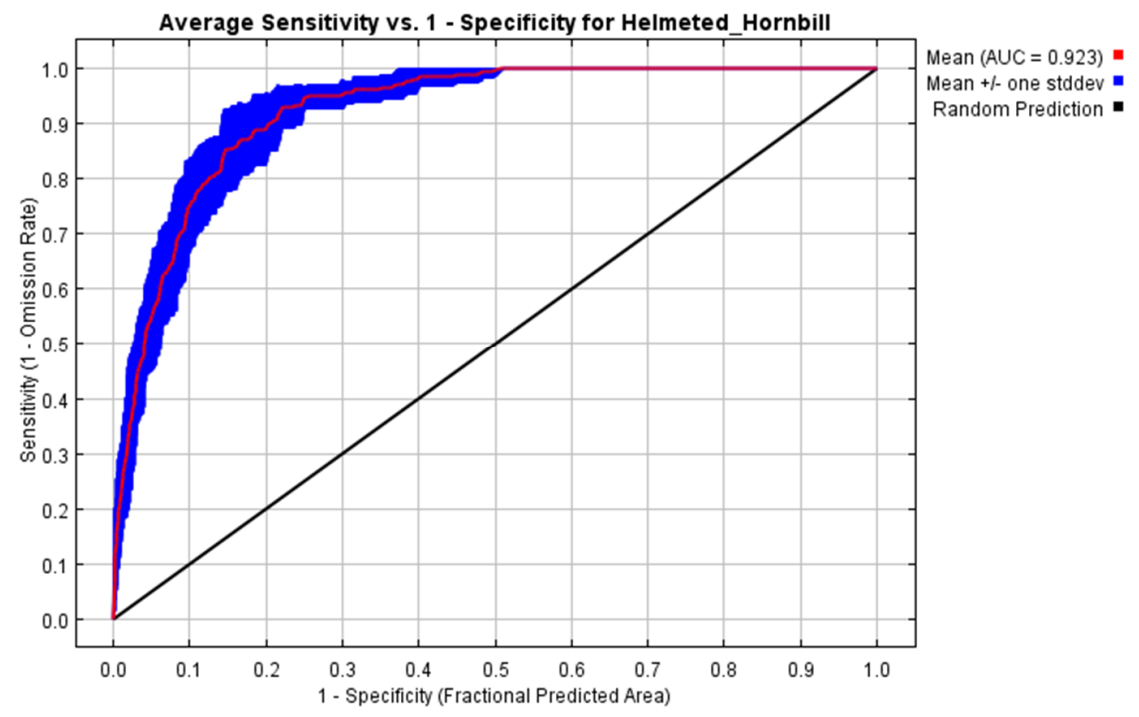

Figure 4. Model accuracy with AUC mean value.

The modeling is according to the suitability of helmeted hornbill habitat in Silokek Geopark area as the result of MaxEnt processing. MaxEnt is able to map the species distribution where the value of each pixel represents the probability of present species in the suitable habitat. In the map below, green color signifies that the zone is more prioritized to conserve which means this area is highly suitable for the Helmeted Hornbill based on preset point data where grey color is not signifies the zone is less prioritized because it has low suitability towards Helmeted Hornbill habitat.

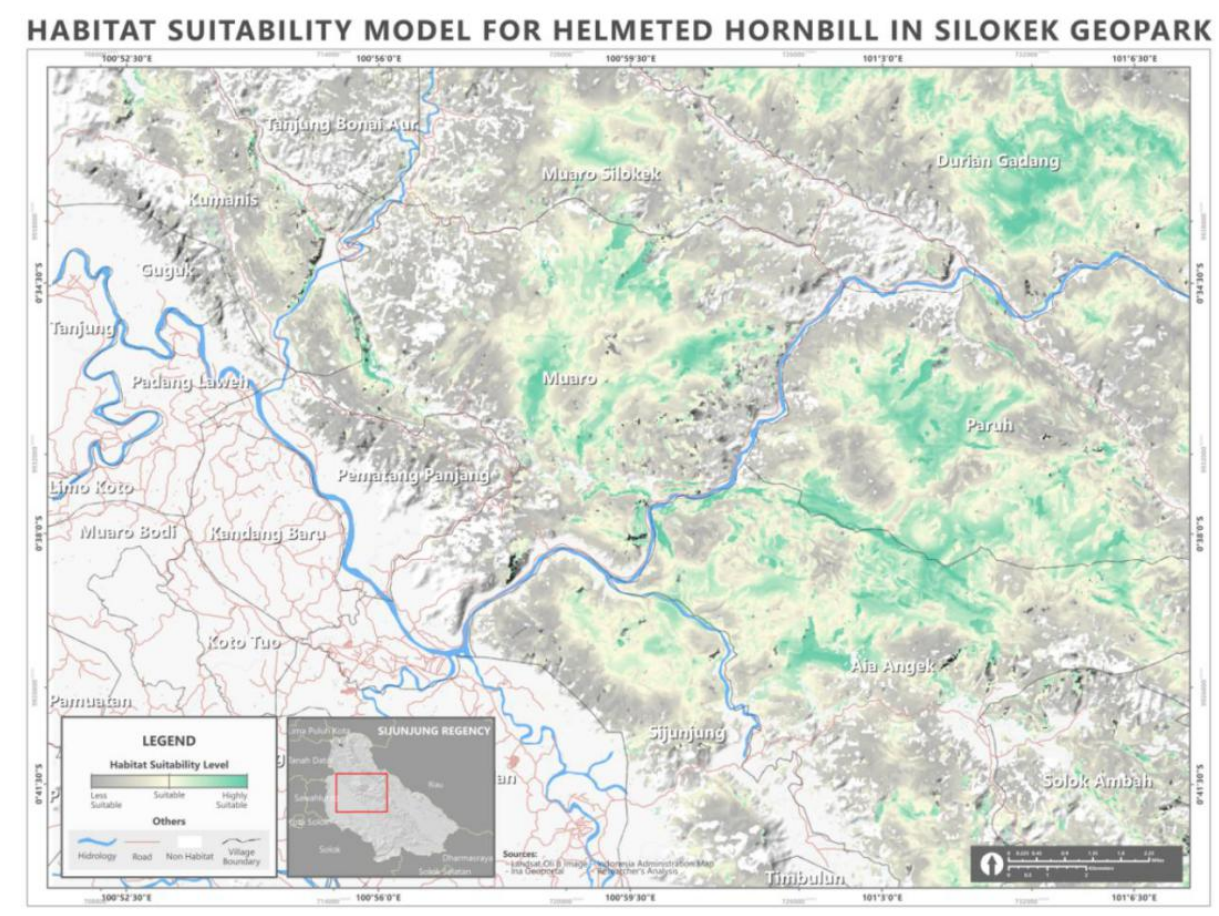

Figure 5. Helmeted Hornbill conservation priority zone in Silokek Geopark.

Based on species present point data, the point positions tend to be in dense canopy forest, riverbank, steep terrain, far from settlement and agriculture, and high elevation. The area abround these present points 
then considered as the priority for the helmeted hornbill conservation in Silokek Geopark Area. We classified the level of conservation priority become three levels (low, moderate, and high).

The potential area to become priority conservation is strongly influenced by environmental variables. Which are basis for consideration environmental data. There is each environmental variable will give effect to the surrounding space. By considering the effect of each of these values and read in the MaxEnt statistical calculation, we succeeded in delineating areas that could be prioritized for potential habitat. It should be limited, that this determination focuses on the fact that the analysis of environmental variables does not involve indicators such as public policy.

The spot area potential for conservation habitat spread in several locations, especially in locations with steep hilly conditions and tight vegetation and far from the reach of human daily activities. The potential area including many district. This table reveals the percentage of each class that occur in $7 \mathrm{sub}$ districts in our area of interest:

Table 2. The percentage of conservation priority level for the helmeted hornbill in Silokek Geopark area.

\begin{tabular}{lcccc}
\hline \multirow{2}{*}{\multicolumn{1}{c}{ Sub District }} & \multirow{2}{*}{ Total Area (Ha) } & \multicolumn{3}{c}{ Percentage (\%) } \\
\cline { 3 - 5 } & & Low & Moderate & High \\
\hline Iv Nagari & 6327.86 & 0.71 & 0.20 & - \\
Koto Tujuh & 3423.79 & 4.49 & 0.47 & 0.05 \\
Kupitan & 656.51 & 0.07 & 0.04 & - \\
Lubuk Tarok & 4634.86 & 0.56 & 0.27 & 0.03 \\
Sijunjung & 45260.00 & 30.65 & 22.40 & 16.55 \\
Sumpur Kudus & 4723.85 & 33.52 & 10.48 & 3.24 \\
Tanjung Gadang & 513.19 & 21.11 & 6.52 & 2.87 \\
\hline
\end{tabular}

\subsection{Variable Contribuition}

Variable contribution in MaxEnt processing will be the ranking of each variable according to the contribution. Table 3 reveals the variable contribution in percent. The table shows the top three variables which have more than $20 \%$ contribution in this model, those are forest texture, distance of patches, and distance of settlement. These variable contributions also show the sort of the influence of variables from the strongest to the weakest. With variable contributions, we can know the factor that can inhibit the Helmeted Hornbill.

Table 3. Variable contribution for the Helmeted Hornbill conservation priority zone

\begin{tabular}{ccc}
\hline Variable & $\begin{array}{c}\text { Percent } \\
\text { contribution }\end{array}$ & $\begin{array}{c}\text { Permutation } \\
\text { importance }\end{array}$ \\
\hline Forest texture & 25.7 & 4.5 \\
Distance of patch & 24.3 & 45.2 \\
Distance of settlement & 22.4 & 20.9 \\
Distance of agriculture & 11 & 6.3 \\
Slope & 7.8 & 8.3 \\
Distance from river & 6.6 & 10.8 \\
Elevation & 2.1 & 3.9 \\
\hline
\end{tabular}

We discovered that forest texture is the highest percent contribution in this modeling. The rougher 
texture of forest indicates the more occurence of Helmeted Hornbill and vice versa.
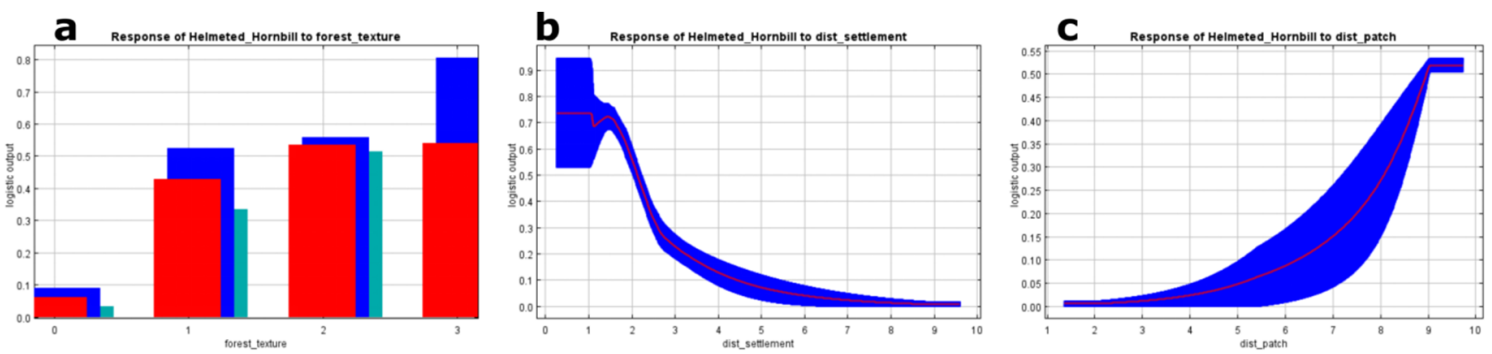

Figure 6. Response charts for the highest variable contributions : a) forest texture, b) distance of settlement, and c) distance of patch.

The response curves above represent how each value of variables correlates with maxent index value in rthe range from 0 to 1 . foret texture as the most contributing variable has four roughness classes (less rough, moderate low, moderate high, and highly rough. We discover the class of this variable which has the highest influence toward the modelling is in moderate high class followed by highly rough and low moderate. This class also indicates as the most potential of occuerence of the helmeted hornbills in Silokek Geopark.

Distance of settlement as the second highest contribution is the result of anthropogenical activity especiall for inhibition and economic ativity. This variable is highly impactful for the occurence of the helmeted horbill. The closer the settlement to the home range of the helmeted hornbill, the higher threat level because the access easiness to their habitat. This factor is suspectible by hunting and deforestation.

The value escalation of maxent result parallelly followed by the value in patch distance. The higher the patch distance value shows better improvement in maxent value. This variable contributes in providing the home rangee of the helmeted hornbil in migration or looking for food source.

This following chart reveals the result of jackknife test toward variable importance. Distance of settlement is the highest regularized traning gain, which means this variable has the most crucial information by itself. When being omitted, this variable decreases the grain the most, which consequently this variable has the most information which is not present within other variables.

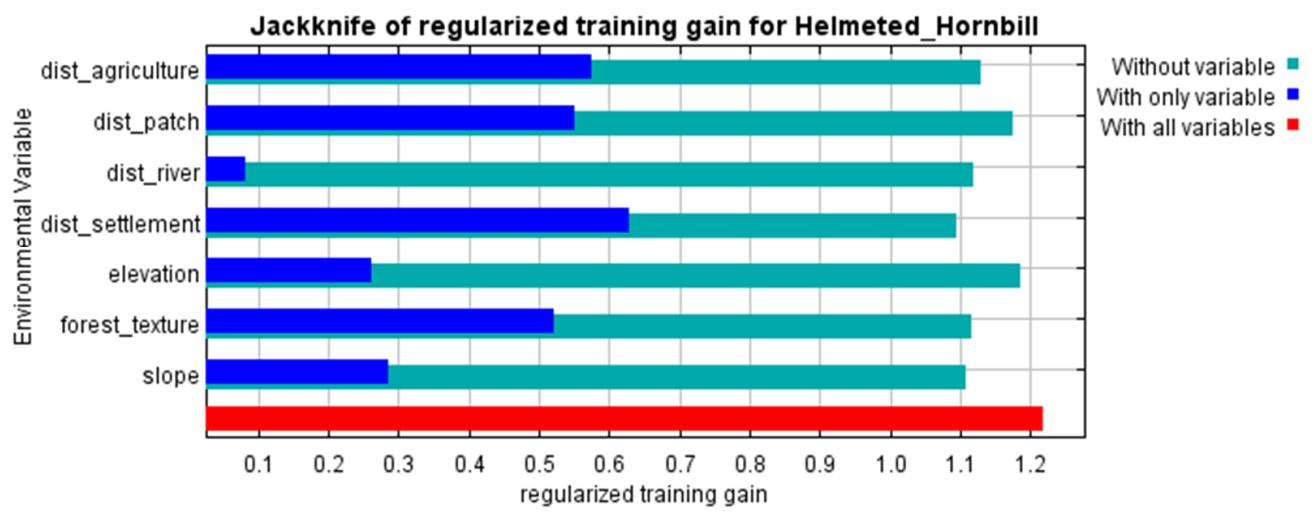

Figure 7. Jackknife test result of variable importance

\section{Discussion}

The main key that is very important in maxent modeling is the present data, if present data on the distribution of hornbill encounters, then statistical prediction analysis of the possible distribution of these animals cannot be carried out. From the selection of environment variables that represent helmeted hornbills habitat indicators that can be spatially analyzed, and represent geographic conditions, this greatly influences the success of the MaxEnt model. The justification for 
this selection certainly has strong reasons. Potential habitat conditions for hornbill conservation such as forest vegetation cover, is one of the main keys in MaxEnt modeling because hornbills themselves live in wet tropical forests. The elevation conditions of potential habitat locations for hornbill conservation are found at locations with high elevations and steep slopes. Following statement Johns, (1988; Kemp, et al., 2017) helmeted hornbills are known live in primary evergreen forest, especially in foothills with wavy topography, but this species is selectively logged forest which still tend natural. This species inhabit in evergreen primary forest. Rough forest texture, wide canopy cover, high trees, and helmeted hornbill toward nesting and food (Jain et. al., 2018). Vegetation density strongly in determining ecosystem connectivity and condition of dense vegetation in the forests provides is important for species survival and biodiversity (Rahman, 2020). The statements from previous researchers strongly support the findings of our study. Where in this study habitat helmeted hornbill in Geopark Silokek it is very clearly that it information vegetation index as the variable forest texture has given a big contribution in this mode. This variable highly affects the most fundamental aspect to delineation of priority conservation areas is in accordance with the requirements of life and the habits of life of helmeted hornbill in Silokek.

The settlement indicator is the second variable that is highly considered in the habitat conservation potential model. Human activities around residential areas become a form of stress pollution on the ivory hornbills, this is because they will feel pressure and threats, because in the area around residential areas there will be competition for land use between animals and humans. Hornbills, which are omnivore birds, will experience a depression in the availability of food around settlements due to land management activities and hunting of animals which are also hornbill food. Nevertheless we made assumption that settlements become an obstacle to connectivity between ecosystems in Silokek. Helmeted Hornbills generally tend to live in the forest which far from human (Kumara, 2006). The high poaching rate toward this species, makes the occurence of human settlement could be threat because the conveinence to access their habitat is near through settelement. The occurence of this species will be much safer if in the deep forest and far from settlement or other artificial landscapes (mining area, industrial, and so forth). But settlement is big impact toward biodiversity. There are some fragmented natural landscape ecosystem areas sorrounded by built-up area (Hidayat, 2019).The anthropogenic or semi natural has altered in massive to development will contributing the real treatment to habitat as dropped habitat capacity (Hanif et al, 2017, 2019).

Distance of patch related to the mobility and home range of this species. The accessibility to different patch helps helmeted hornbill in exploring the food source, nest, or migration destination. Habitat patches are the key variable in this model, because ecologically this will affect the distance between the habitat patches to migrate for these species. Habitats that are fragmented due to logging do not always provide large trees capable of supporting hornbills to build nests for breeding. The consequence of the distance between habitats is the migration capacity and availability of food supplies in fragmented habitats. There has interpreted that from looking at the NDVI value which represents the forest texture in the habitat patch. It is unlikely that the area will be able to supply the ecological characteristics that are generally favored by ivory hornbills. Based on statements in previous research, it truly related with output research, where the nest made at natural cavity in large living tree. The cavity which could nest this species is on the large and tall tree. Related to the tree, fruit is available food which is also as tall and large tree. In addition, the dependence of the ivory hornbill on the presence of a sturdy and strong tree for nesting can also indicate the health level of an ecosystem (Jain et. al., 2018; KLHK, 2018). Poonswad et al. (2013), in radi-tracking surveys of the related Great Hornbill (Buceros bicornis) from Kao Yai National Park in Thailand show that daily movement of male can over $0.7-6 \mathrm{~km}^{2}$, and up to $7 \mathrm{~km}^{2}$ during the breeding season. It is compared in (Jait et al. 2018) that Helmeted Hornbills have a more specialised diet that Great Hornbills, and their home range is consequently likely to be greater. This variable also determines how the mobility of Helmeted Hornbills in isolated patch could access larger patch as the core area. In the prespective of Helmeted Hornbills, fragmented habitat is still able to provide the resource to espouse their population in nature (KLHK, 2018).

The effectiveness of conservation priority areas, from the analysis map it is clear that the potential habitat for conservation is scattered in many locations, further consideration needs to be done in this analysis. Conservation should not only measure areas with conservation under law status. It is feared that the imbalance of population size and habitat availability in the future. If the focus of conservation it is only in conservation legal status, so species that are scattered in non-conservation areas will be easily hunted down and killed to be traded. 
The ivory hornbill has not become a priority issue, so monitoring activities and funding are still limited. Hunting is carried out outside the conservation area (KLHK, 2018). As well the environmental and forestry ministry police on protective personnel in the conservation area remain very meager (Arinta, 2017). Effective conservation actions should thus not focused on protecting their natural habitat and enhancing the connectivity however the action plan also curtail the illegal trade and their derivatives (Hanif et al. 2019;2020). Green political theory is a compatible theory analyses problem that countries should do in managing resources and making non-deskctional polices again the environment, and it can also recognize Indonesia barrier to the foreign bink-based ivory trade (Arinta,2017). This theory need binding agreement and international law, law designed to regulate the difference in purpose and solve environment issue, and it also state a disciplinary action is required in an institution, thereby affecting the effectiveness of the institution (Arinta, 2017)

\section{Conclusion}

The environmental variables used in the study include slope, distance from river, forest texture, distance from settlements, elevation, distance from agriculture, and distance patches. Helmeted hornbill tend to be in dense canopy forest, riverbank, steep terrain, far from settlement and agriculture, and high elevation. Contribution from the MaxEnt the top three variable which have more than $20 \%$, that are forest texture, distance of patches, and distance of settlement.

\section{Acknowledgement:}

\section{References}

Arinta, N. (2017). Upaya Indonesia dalam penanganan wildlife trafficking: Perdagangan Rangkong Gading ke Tiongkok periode 2012-2015 [Skripsi]. Jakarta: UIN Syarif Hidayatullah .

Azizah, N. (2010). Perencanaan wisata Burung Rangkong (Famili Bucertotidae) di Harapan Rainforest Kabupaten Batanghari, Provinsi Jambi. Departemen Konservasi Sumberdaya Hutan dan Ekowisata, Fakultas Kehutanan Institut Pertanian Bogor.
Baldwin, R. (2009). Use of maximum entropy modeling in wildlife research. Entropy, 11 : $864-866$.

Beastall, C., Shepered, C., Hadiprekarsa, Y., \& Martyr, D. (2016). Trade in the Helmeted Hornbill Rhinoplax vigil : the 'ivory hornbill'. . Bird Conservation International, $26: 137$ - 146.

Brotons, L., Thuiller, W., Araujo, M., \& Hirzel, A. (2004). Presence-absence versus presence-only modeling methods for predicting bird habitat suitability. Ecography, $27: 437$ - 488.

Cody, M. (1985). Habitat Selection in Birds. New york: Academid Press.

Elith, J., Phillips, S., Hastie, T., Dudl'k, M., Chee, Y., \& et, a. (2011). A statistical explanation of MaxEnt for ecologists. Divers Distrib, 17 : 43-47.

Hadiprakarsa, Y., \& Kinnaird, M. F. (2004). Foraging characteristics of an assemblage of four Sumatran hornbill species. Bird Conservation International, 14 : S53-S62.

Jain, Jain , A., Lee J, G. H., Chao, N., Lees , C., Orenstein, R., . . . Rao M, (. (2018). . Helmeted Hornbill (Rhinoplax vigil): Status Review, Range-wide Conservation Strategy and Action Plan (2018-2027). IUCN Species survival Commission Hornbill Specialist Group.

Johns, A. (1988). Effects of " selective" timber extraction on rain forest structure and composition and some consequences for frugivores and folivores. Biotropica, 31-37.

Kaur, R., Ancrenaz, M., Ramli , R., \& Singh, S. (2019). Observations at a nest of 
Helmeted Hornbill Rhinoplax vigil in Borneo, Malaysia. Forktail, 34. 68-73.

Kemp, A. (1995). The Hornbills. New York: Oxford University Press.

Kinnaird, M., \& T.O'Brien. (2007). The Ecology and Conservation of Asian Hornbills: Farmers of the Forest. Chicago: University of Chicago Press.

Kitamura, S. (2011). Frugivory and seed dispersal by hornbills (Bucerotidae) in tropical forests. Acta Oecologica, 37: 531-541.

Kitamura, S., Thong-Agree, S., Madsri, S., \& Poonswad, P. (2011). Characteristics of Hornbill-dispersed Fruits in Lowland Dipterocarp Forests of Southern Thailand. The Raffles Buleetin of Zoology 2011, Suplement No 24: 137-147.

KLHK. (2018). Strategi Dan Rencana Aksi Konservasi Rangkong Gading (Rhinoplax Vigil) Indonesia 2018-2028.

Krishnasamy, K., Leupen, B., \& O.C, O. (2016). Observations of the Helmeted Hornbill Trade in Lao PDR. TRAFFIC Malaysia, 24 pp.

Kumara, I. (2006). Karakteristik Spasial Habitat Burung Rangkong Di Taman Nasional Danau Sentarum. Bogor: Tesis Sekolah Pascasarjana Institut Pertanian Bogor.

Kusuma, D. (2019). Geopark Silokek Sijunjung Menuju UNESCO Global Park. Jurnal Pembangunan Nagari, Volume 4 Nomor 1 Edisi Juni 2019 : 17-32.

Lum, S., \& P, P. (2005). The Ecology of Hornbills: reproduction and populations. Proceedings of the 3rd International
Hornbill Workshop (p. 248 ). Thailand: Hornbill Research Foundation.

Mcdermic, G., Franklin, S., \& LeDrew, E. (2005). Remote sensing for large-area habitat mapping. Progress in Physical GeographyPROG PHYS GEOG, 29. 449474.10.1191/0309133305pp455ra.

Muharram, N. A., Ramadhani, F., \& Putra, B. G. (2020). ) Optimalisasi Data Digital Terrain Model Untuk Pembuatan 3d Fisiografis Dan Geomorfologi Geopark Silokek. e-issn 2622. DOI: 10.31851/swarnabhumi.v5il.3373.

Naniwadekar, R., U, S., K, I., \& A, D. (2015). Reduced hornbill abundance associated with low seed arrival and altered recruitment in a hunted and logged tropical forest. Plos One, 10: e0120062.

Nur, F. e. (2013). Kelimpahan dan Distribusi Burung Rangkong (Famili Bucerotidae) di Kawasan PT. Kencana Sawit Indonesia (KSI), Solok Selatan, Sumatera Barat. Prosiding Seminar FMIPA Universitas Lampung. Lampung.

Perumal, K., \& Bhaskaran, R. (2010). Supervised Classification Performance of Multispectral Images. Journal of Computing, Volume 2, Issue 2: 124:129.

Philips, S. J., \& Dudi'k, M. (2008). Modeling of species distributions with Maxent: new extensions and a comprehensive evaluation. Ecography, 31: 161175.

Phillips, S. J., Anderson, R. P., \& Schapire, R. E. (2006). Maximum entropy modeling of species geographic distributions. Ecol. Model, 2006, 190, 231-259. 
Poonswad, P., Kemp , A., \& Strange, M. (2013). Hornbills of the World: A Photographic Guide. Draco Publishing and Hornbill Research Foundation, 212 pp.

Poonswad, P., Kemp, A., \& Strange, M. (2013). Hornbills of the World: A Photographic Guide. Draco Publishing and Hornbill Research Foundation, 212 pp.P.

Rahman, H. (2020). Spatial Assessment of Landscape Structure Changes and Ecological Connectivity in Pariaman. Journal of Remote Sensing GIS \& Technology, Volume-6, Issue-2 (MayAugust).

Walker, J. (2007). Dietary specialization and fruit availability among frugivorous birds on Sulawesi. Ibis, 149: 345-356.

Yang, X. Q., Kushwaha S, P. S., Saran, S., Xu, J., \& Roy, P. S. (2013). Maxent modeling for predicting the potential distribution of medicinal plant, Justicia adhatoda L. in Lesser Himalayan foothills. Ecol. Eng, 2013, 51, 83-87. 